\title{
Comparative Evaluation of Inductively Coupled Plasma-Optical Emission Spectrometry and Colorimetry for Determining Phosphorus in Grain Samples
}

\author{
Kanwar L. Sahrawat, Swati Chaudhury, K. Srinivasu \& Suhas P. Wani
}

To cite this article: Kanwar L. Sahrawat, Swati Chaudhury, K. Srinivasu \& Suhas P. Wani (2016):

Comparative Evaluation of Inductively Coupled Plasma-Optical Emission Spectrometry and Colorimetry for Determining Phosphorus in Grain Samples, Communications in Soil Science and Plant Analysis, DOI: 10.1080/00103624.2016.1146895

To link to this article: http://dx.doi.org/10.1080/00103624.2016.1146895

Accepted author version posted online: 22

Feb 2016.

Submit your article to this journal $\square$

Џll Article views: 6

View related articles \ulcorner

View Crossmark data \lceil 


\title{
Comparative Evaluation of Inductively Coupled Plasma-Optical
}

\section{Emission Spectrometry and Colorimetry for Determining}

\author{
Phosphorus in Grain Samples
}

\begin{abstract}
Kanwar L. Sahrawat, Swati Chaudhury, K. Srinivasu, and Suhas P.Wani
International Crops Research Institute for the Semi-Arid Tropics (ICRISAT), Patancheru, Telangana State, India

Address correspondence to Swati Chaudhury, International Crops Research Institute for the Semi-Arid Tropics (ICRISAT), 502 324, Patancheru, Telangana State, India. Email: schaudhury9@gmail.com.
\end{abstract}

\begin{abstract}
The inductively coupled plasma (ICP)-based method provides the opportunity to determine phosphorus (P) along with other major, secondary, micro and trace elements in plant materials. This study was conducted to compare and evaluate the relative efficacy of the inductively coupled plasma-optical spectrometry (ICP-OES) method with that of colorimetric method using Skalar autoanalyzer, for determining $\mathrm{P}$ in 428 grain samples of 8 diverse crops. The results on grain P analysis by the two methods, for individual as well as for all crop samples combined, showed that were highly positively correlated ( $\mathrm{r}$ varied from 0.84 to $0.98, \mathrm{p}<0.0001$ for the 8 crops, and $\mathrm{R}^{2}$ for all crop grain samples was $\left.0.9201, \mathrm{p}<0.0001\right)$. And the precision by the ICP
\end{abstract}


method was similar to that determined by the Skalar method. Our results demonstrate that the ICP-OES method can be conveniently used for determining $\mathrm{P}$ along with other plant nutrient elements in grain samples of diverse crops.

Keywords Colorimetric method, ICP-OES, phosphorus in grain, precision

\section{INTRODUCTION}

Phosphorus (P) deficiency is especially widespread in the soils of tropical regions of the world (Sahrawat et al. 2001; Bationo et al. 2008). In the ICRISAT analytical service laboratory, $\mathrm{P}$ in plant materials, including grain samples of various crops, is routinely determined by the colorimetric method using Skalar autoanalyzer. However, with the availability of the inductively coupled plasma-optical emission spectrometer (ICP-OES) in our laboratory, we have an opportunity to determine $\mathrm{P}$ in plant samples by using ICP-OES as well. Indeed, this provides a very convenient method to determine $\mathrm{P}$ along with all other major-, micro- and trace elements in plant materials including grain samples. And we wanted to evaluate the results obtained by the ICP-OES-OES based method with the standard colorimetric method using Skalar autoanalyzer.

In earlier studies, we have observed that in general the ICP-AES (atomic emission spectrometer) method was far more sensitive than the turbidimetric method for the determination of extractable sulfur (S) (Shirisha et al. 2010), and the ICP-OES method was more sensitive than the colorimetric method for determining extractable boron (B) (Sahrawat et al. 2012) in diverse soils. The objective of this study therefore, was to comparatively evaluate the Skalar and ICPOES based methods for determining total $\mathrm{P}$ in grain samples of diverse crops including cereals, legumes and oilseeds. 


\section{MATERIALS AND METHODS}

\section{Grain Samples}

A total of 428 grain samples were selected to include a range of crops varying from cereals (pearl millet, sorghum, maize and rice), pulses (pigeonpea and chickpea) and oilseed (groundnut and sunflower) crops. The grain samples were dried at $60^{\circ} \mathrm{C}$ for $48 \mathrm{~h}$ before grinding the samples for total $\mathrm{P}$ analysis by the ICP-OES and Skalar methods. Determination of $\mathrm{P}$ in grain sample by ICP-OES

Finely ground, dried grain samples were weighed $(0.30 \mathrm{~g})$ in $50 \mathrm{ml}$ polypropylene $(\mathrm{PP})$ tubes. Two $\mathrm{ml}$ of concentrated nitric acid $\left(\mathrm{HNO}_{3}\right)$ and $0.5 \mathrm{ml}$ of $30 \%$ hydrogen peroxide $\left(\mathrm{H}_{2} \mathrm{O}_{2}\right)(\mathrm{w} / \mathrm{v})$ solution was added in that sequence, in each tube. Along with the samples, a number of blanks were included (with $\mathrm{HNO}_{3}$ acid and $\mathrm{H}_{2} \mathrm{O}_{2}$ ). After properly mixing the contents in the tubes, they were kept for cold digestion over night at room temperature $\left(25^{\circ} \mathrm{C}\right)$. Next morning, the contents in the tubes were mixed, and placed in DigiPrep digestion blocks (SCP Scientific, Quebec, Canada) with a set temperature programming (room temperature to $80^{\circ} \mathrm{C}$ in $30 \mathrm{~min}$. hold time 1 $\mathrm{h}$, and then in $15 \mathrm{~min}$. rise of temperature from $80^{\circ} \mathrm{C}$ to $125^{\circ} \mathrm{C}$ and final hold time $2 \mathrm{~h}$ ). The tubes were cooled and volume made up to $25 \mathrm{ml}$ with distilled water. The contents of the tubes were mixed thoroughly for $1 \mathrm{~min}$. The solution was filtered through Whatman filter paper number 1; and an aliquot from the digest was used for phosphorous analysis in ICP-OES (Prodigy, Teledyne Leeman, Hudson, N. H., USA). Detailed description of the method used is provided in Wheal et al. (2011). 


\section{Determination of $\mathbf{P}$ in Grain Sample by Skalar}

Finely ground grain samples $(0.3 \mathrm{~g})$ were digested in $75-\mathrm{ml}$ digestion tubes by adding $2.5 \mathrm{ml}$ of concentrated sulfuric acid-selenium (Se) mixture (sulfuric acid containing $0.4 \% \mathrm{Se}$, v/w, was heated to dissolve Se) (Sahrawat et al. 2002), and P in the digests was analyzed using Skalar autoanalyzer. All the grain samples were analyzed in three replications, and the results presented are the means of three independent analyses.

The data were statistically analyzed, and significance of the results by the two methods for $\mathrm{P}$ analysis was also tested. Correlations between the values of total $\mathrm{P}$ in grain samples by the ICP and Skalar methods were also determined.

\section{RESULTS AND DISCUSSION}

The results on the $\mathrm{P}$ concentration in grain samples of 8 crops determined by the ICP-OES method were highly positively correlated with the values determined by the Skalar colorimetric method; and the value of correlation coefficient $r$ varied from 0.84 to $0.98(\mathrm{p}<0.0001)$ for the 8 crops (Table 1).

The relationship between the values of $\mathrm{P}$ concentrations determined by the ICP-OES method was highly positively correlated that that determined by the Skalar colorimetric method, considering all grain samples of all 8 crops (Figure 1); and the results were represented by the following regression equation:

Skalar-P $(\%)=0.0227+0.890 \operatorname{ICP}-\mathrm{P}(\%), \mathrm{R}^{2}=0.9201(\mathrm{n}=428)$ 
The precision obtained in determining total $\mathrm{P}$ in grain samples by the ICP and Skalar methods, as judged by the range, mean and standard deviation (SD) values, was similar and comparable for grain samples of 8 crops individually as well for all crops combined (Table 2).

Our results on the analysis of total $\mathrm{P}$ in grain samples of 8 diverse crops by the ICP-OES method suggest that the method can be conveniently used for the determination of total $P$ in grain samples of crops along with other plant nutrient elements. Indeed, the ICP-based methods provide an opportunity to determine $\mathrm{P}$ along with other major, micro and trace nutrient elements in diverse plant materials.

\section{REFERENCES}

Bationo, A., J. Kihara, B. Vanlauwe, J. Kimetu, B. S. Vaswa, and K. L. Sahrawat. 2008.

Integrated nutrient management concepts and experience from Sub-Saharan Africa.

In Integrated nutrient management for sustainable crop production, eds. M. S. Aulakh and C. A. Grant, 467-521. New York, USA: The Haworth Press, Taylor and Francis Group.

Sahrawat, K. L., M. K. Abekoe, and S. Diatta. 2001. Application of inorganic phosphorus

fertilizer. In Sustaining fertility in West Africa. Soil Science Society of America Special

Publication no. 58, eds. G. Tian, F. Ishida, and D. Keatinge, 225-246. Madison, WI, USA: Soil Science Society of America and American Society of Agronomy.

Sahrawat, K. L., G. Ravi Kumar, and K. V. S. Murthy. 2002. Sulfuric acid-selenium digestion for multi-element analysis in a single plant digest. Communications in Soil Science and Plant Analysis 33:3757-3765. 
Sahrawat, K. L., K. Shirisha, K. V. S. Murthy, P. N. Gajbhiye, S. Kundu, S. P. Wani, and G.

Pardhasaradhi. 2012. Comparative evaluation of inductively coupled plasma-atomic emission spectroscopy and colorimetric methods for determining hot water-extractable boron in soils. Communications in Soil Science and Plant Analysis 43:948-957.

Shirisha, K., K. L. Sahrawat, K. V. S. Murthy, S. P, Wani, P. N. Gajbhiye, and S. Kundu. 2010. Comparative evalustion of ICP-AES and turbidimetric methods for determining extractable sulfur in soils. Journal Indian Society of Soil Science 58:323-326.

Wheal, M. S., T. O. Fowles, and L. T. Palmer. 2011. A cost-effective acid digestion method using closed polypropylene tubes for inductively coupled plasma optical emission spectrometry (ICP-OES) analysis of plant essential elements. Analytical Methods 3:28542863. 
Table 1 Relationship between P (\%) measured by Skalar autoanalyzer (Skalar-P) and inductively coupled plasma- optical emission spectrometer (ICP-P) in grain samples of eight crops

\begin{tabular}{|l|l|l|l|l|}
\hline Crops & $\begin{array}{l}\text { No of samples } \\
(\mathrm{n})\end{array}$ & Regression equation & $\begin{array}{l}\text { Correlation } \\
\text { coefficient } \\
(\mathrm{r})\end{array}$ & p-value \\
\hline $\begin{array}{l}\text { Pearl } \\
\text { millet }\end{array}$ & 28 & Skalar-P $=0.0259+0.8878$ ICP-P & $0.88^{* * *}$ & $<0.0001$ \\
\hline Maize & 44 & & & \\
\hline Rice & 45 & Skalar-P $=0.0505+0.8083$ ICP-P & $0.88^{* *}$ & $<0.0001$ \\
\hline Sorghum & 74 & Skalar-P $=0.0021+0.9847$ ICP-P & $0.98^{* *}$ & $<0.0001$ \\
\hline Chickpea & 50 & Skalar-P $=0.0462+0.7447$ ICP-P & $0.84^{* *}$ & $<0.0001$ \\
\hline Pigeonpea & 58 & Skalar-P $=0.0095+0.9404$ ICP-P & $0.95^{* *}$ & $<0.0001$ \\
\hline Groundnut & 91 & Skalar-P $=-0.0002+0.9591$ ICP-P & $0.95^{* *}$ & $<0.0001$ \\
\hline Sunflower & 38 & Skalar-P $=0.0725+0.7683$ ICP-P & $0.85^{* *}$ & $<0.0001$ \\
\hline
\end{tabular}


Table 2 Precision obtained in the determination of $\mathrm{P}$ in grain samples of seven crops by the ICP (ICP-P) and Skalar (Skalar-P) methods for determining P in grain samples of eight crops

\begin{tabular}{|c|c|c|c|}
\hline Crops & & ICP-P (\%) & Skalar-P (\%) \\
\hline Pearl millet & $\begin{array}{l}\text { Range } \\
\text { Mean } \\
\text { SD }\end{array}$ & $\begin{array}{l}0.16-0.29 \\
0.22 \\
0.04\end{array}$ & $\begin{array}{l}0.16-0.31 \\
0.22 \\
0.04\end{array}$ \\
\hline Maize & $\begin{array}{l}\text { Range } \\
\text { Mean } \\
\text { SD }\end{array}$ & $\begin{array}{l}0.17-0.38 \\
0.26 \\
0.05\end{array}$ & $\begin{array}{l}0.16-0.35 \\
0.26 \\
0.04\end{array}$ \\
\hline Rice & $\begin{array}{l}\text { Range } \\
\text { Mean } \\
\text { SD }\end{array}$ & $\begin{array}{l}0.18-0.38 \\
0.30 \\
0.04\end{array}$ & $\begin{array}{l}0.16-0.37 \\
0.30 \\
0.04\end{array}$ \\
\hline Sorghum & $\begin{array}{l}\text { Range } \\
\text { Mean } \\
\text { SD }\end{array}$ & $\begin{array}{l}0.15-0.47 \\
0.27 \\
0.06\end{array}$ & $\begin{array}{l}0.14-0.38 \\
0.25 \\
0.05\end{array}$ \\
\hline Chickpea & $\begin{array}{l}\text { Range } \\
\text { Mean } \\
\text { SD }\end{array}$ & $\begin{array}{l}0.20-0.74 \\
0.40 \\
0.11\end{array}$ & $\begin{array}{l}0.21-0.69 \\
0.40 \\
0.11\end{array}$ \\
\hline
\end{tabular}




\begin{tabular}{|l|l|l|l|}
\hline & & & \\
\hline Pigeonpea & Range & $0.26-0.58$ & $0.23-0.56$ \\
& Mean & 0.38 & 0.36 \\
& SD & 0.07 & 0.07 \\
\hline Groundnut & Range & $0.28-0.57$ & $0.26-0.51$ \\
& Mean & 0.42 & 0.40 \\
\hline Sunflower & SD & 0.06 & 0.05 \\
& Range & $0.32-0.86$ & $0.27-0.78$ \\
& Mean & 0.49 & 0.46 \\
& SD & 0.13 & 0.11 \\
& SD & 0.11 & 0.10 \\
\hline All crops & Range & $0.15-0.86$ & $0.14-0.78$ \\
& Mean & 0.30 & 0.29 \\
\hline
\end{tabular}


Figure 1. Relationship between Skalar-P and ICP-P in 428 grain samples of 8 crops

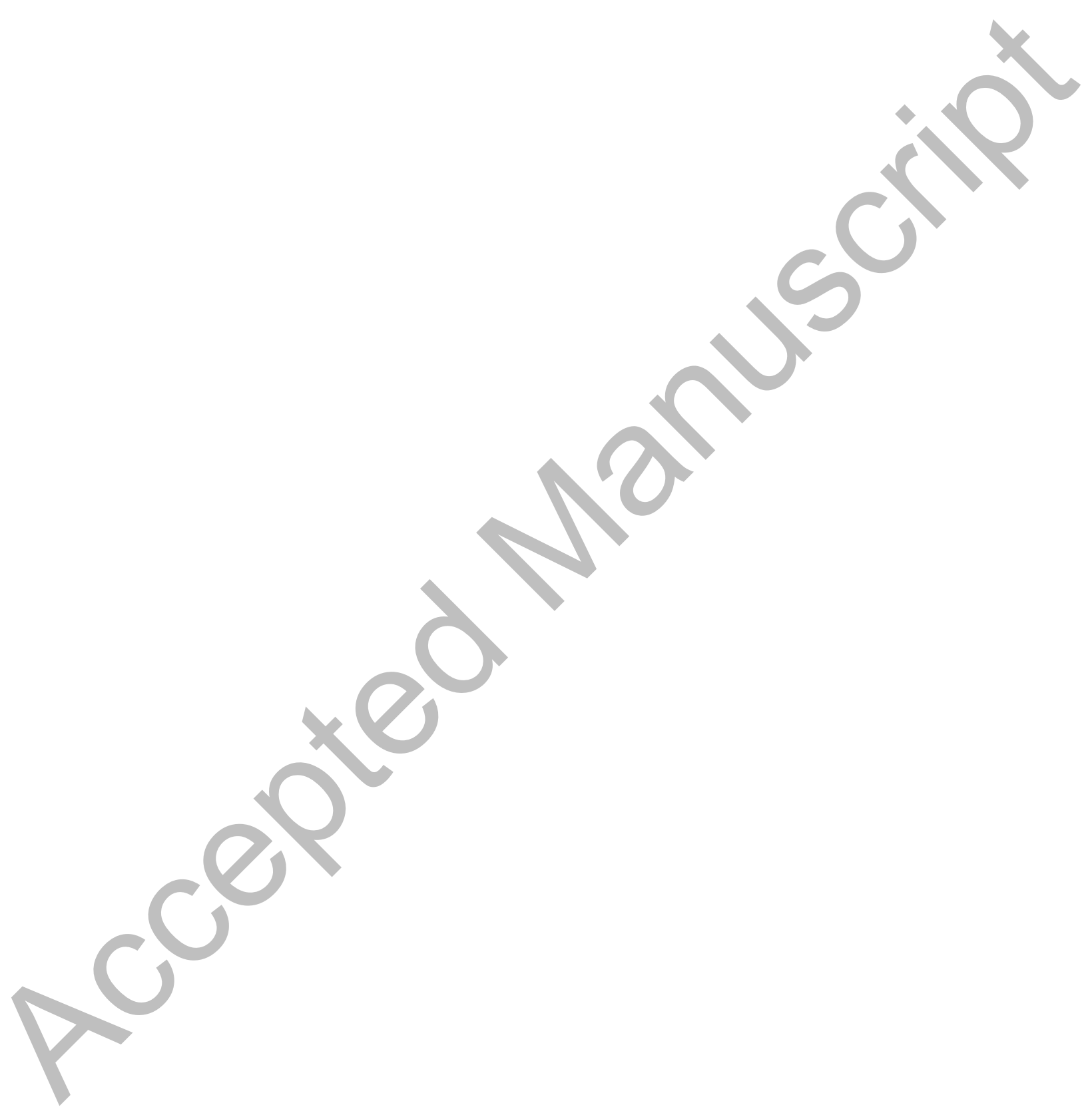

